\title{
The rise of Stalinism in the NHS
}

Recently I sat at dinner between a senior nurse and a senior NHS manager, and much of the talk was of Stalinism in the NHS. These people were convinced that the NHS was becoming an organisation in which people were terrified to speak the truth. This opinion is heard time and time again, and everybody seems convinced that it is becoming worse. We thought that it would be useful to consider this issue, and the following three articles look at examples of the suppression of information within the NHS, the historical context of regional directors of public health being gagged, and the fact that Britain is an unfree society with an unfree press.

Censorship has a long tradition in Britain, and the ruling classes instinctively suppress information. The English poet fohn Milton knew strict censorship at the beginning and the end of his life, but free speech flowered briefly in the middle of the 17th century. At this time Milton published the "Areopagitica", which perhaps better than any other document gives the arguments for free speech.

\section{Secrecy in the NHS}

\author{
Naomi Craft
}

Seven years ago we collected 20 examples of secrecy surrounding health and the NHS in Britain. ${ }^{1}$ This month we repeated the exercise, and in three days we have discovered 30 examples. We will be pleased to hear of more.

\section{Trust contracts}

(1) Paragraph 330 of the Terms and Conditions of Service for Hospital Medical and Dental Staff says that "A practitioner shall be free, without prior consent of the employing authority, to publish books, articles, etc, and to deliver any lecture or speak, whether on matters arising out of his or her hospital service or not." A growing number of trust hospitals have contracts which have replaced this with a gagging clause.

The BMA's database records the following trusts as having at some time inserted a confidentiality or conflict of interest clause, or both, into contracts: Frimley Park Hospital; Walsgrave Hospital; St Helens and Knowsley Community Health; Mid Staffordshire General Hospitals; North Staffordshire Hospital Centre; Leicester Royal Infirmary; Royal Devon and Exeter Hospital; Ashford Hospital, Middlesex; and Heatherwood and Wexham Park Hospitals. For example, a recent confidentiality clause from a contract given to a consultant working for West Kent Health Authority reads: "In the course of your work you may have access to confidential information which should not be disclosed to any other person unless in the pursuit of your duties or with the specific permission of the employing authority."

Hansard reports that in March 1994, Dawn Primarolo (then opposition spokesperson for health) asked the secretary of state for health "what freedom NHS trusts have to vary the terms and conditions for service for hospital medical and dental staff in relation to the freedom of practitioners to publish articles or to speak on any issue without the prior consent of their employer." The health minister, Brian Mawhinney,
"Give me," wrote Milton, "the liberty to know, to utter, and to argue freely according to conscience, above all liberties." Truth, he argued, was never "put to the worse in a free and open encounter.... It is not impossible that she [truth] may have more shapes than one.... If it come to prohibiting, there is not ought more likely to be prohibited than truth itself, whose first appearance to our eyes bleared and dimmed with prejudice and custom is more unsightly and implausible than many errors."

We can never develop the NHS and the health of the British people without a lively debate, which will be debased if people cannot say what they truly believe. "Where there is much desire to learn," wrote Milton, "there of necessity will be much arguing, much writing, many opinions; for opinion in good men is but knowledge in the making."

Perhaps these truths should be quoted on the front page of all the many annual reports of the NHS.-RICHARD SMITH, editor, BMJ
$B M J$, London W1CH 9JR

Naomi Craft, editorial registrar

$B M F$ 1994;309:1640-5 replied in a written answer that "Trusts have freedom to recruit staff on new terms and conditions and can negotiate new terms with existing staff."

Ms Primarolo then asked whether doctors employed by NHS trusts are "guaranteed the same rights of free speech as apply under paragraph 330 of the Whitley Council agreement for doctors employed by health authorities." Dr Mawhinney replied that "Doctors have rights specified in their contracts."

In September 1994 Dr Sandy Macara, chairman of the council of the BMA, wrote to Virginia Bottomley asking for reassurances about the inclusion of paragraph 330 in trust contracts. Gerry Malone, health minister, replied in October 1994 that "We have considered carefully, but are unable to agree to the imposition of such a requirement in trusts. It will, therefore, be for trusts to determine the provisions they consider appropriate in this respect."

Andrew Foster, controller of the Audit Commission, which last month reported on fraud in the NHS, said that "the culture of honesty and high integrity in British public service is something that needs to be sustained. Half of all fraud is detected by staff who spot something dodgy and report it. One of the best antidotes to fraud is an open attitude with staff." The independent campaign group, the NHS Support Federation, welcomed the publication of the report, but Michael Walker, campaign director of the federation said, "Since the establishment of NHS trusts, all too many trusts have relentlessly sought to clamp down on NHS staff's freedom to speak out, by introducing 'gagging clauses,' victimising or even sacking NHS staff who speak out about poor standards. This has led to a growing climate of fear in the NHS-not an 'open attitude with staff', as referred to by the Audit Commission."

\section{Access to government information}

(2) Under the Code of Practice on Access to Government Information introduced in April 1994, Whitehall 


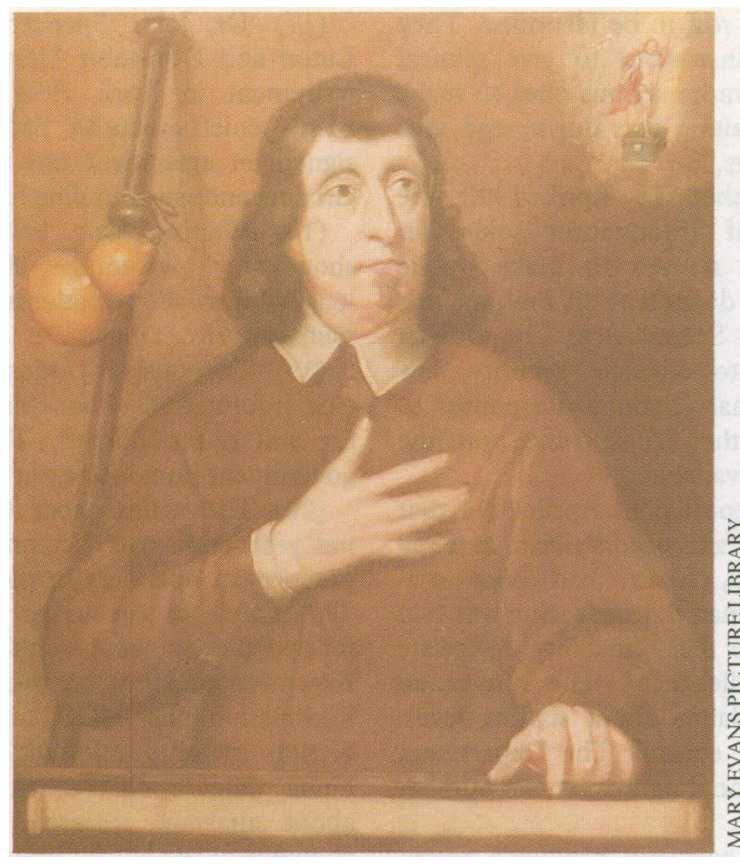

Milton argued eloquently for free speech

departments are obliged to give information on request unless it falls into one of 15 exempt categories. Departments have been allowed to set their own fees. The Cabinet Office guidance on the code says that fees "act as an important reminder to the public that providing information costs money" and says charges should be made for requests which lead to additional work.

In November 1994 the Campaign for Freedom of Information found that some departments were charging huge sums for information under the new code. For example, the Public Health Laboratory Service said it would charge between $£ 2000$ and $£ 3000$ to identify local authorities who have reported salmonella food poisoning incidents related to eggs since 1988. The Department of Health says that any request needing more than one hour of staff time will lead to charges of $£ 20$ an hour. "An hour is just enough for officials to get a cup of tea brewed and decide which filing cabinet the papers are kept in. Fees of this kind could have been designed to ensure no one gets any information out of departments," said Maurice Frankel, director for the Campaign for Freedom of Information.

Complaints about unjustified refusals to give information, or unreasonable charges, can be made to the parliamentary ombudsman. The ombudsman, $\mathbf{M r}$ William Reid, recently forced the Department of Health to release information about talks it claimed to have held with pharmaceutical industry representatives.

(3) In a letter to New Scientist Mr Frankel highlighted the problem of the secrecy clause, Section 118 of the 1968 Medicines Act, which blocks the release of any information obtained under the act's powers. ${ }^{2}$ Citing the clause, Mr Frankel writes that "Ministers have refused to reveal: what research has been received on the effects of AZT [zidovudine]; what reasons the Committee on the Review of Medicines gave for refusing to renew a licence for Pegina, a herbal medicine; what research on organophosphorus sheep dips has been supplied to the Ministry of Agriculture; what information is held on the sale of counterfeit medicines; what information was considered during a review of alcohol levels in gripe water; which pharmaceutical plants have been inspected by medicines inspectors; which hospitals are taking part in clinical trials of a new drug; and what discussions have taken place about safeguarding myxomatosis vaccine supplies for pet rabbits.”

In 1993 the government rejected Giles Radice's Medicines Information Bill, which was designed to remove legal restrictions on disclosure.

\section{Political statements}

(4) John Smith, the former leader of the Labour party, decided to visit St Bartholomew's Hospital accident and emergency department, as part of the local election campaign, in April 1994, just before he died. Initially, the hospital agreed to the visit. Shortly afterwards it withdrew its agreement, quoting Department of Health guidelines. These guidelines state that within the pending period for the local elections no party political publicity should be allowed on NHS hospital premises. Mr Smith wrote to John Major, the prime minister, the day before his proposed visit to ask why $\mathrm{Mr}$ Major had been able to make a visit to Basildon Hospital maternity unit on 5 April in a blaze of publicity, which also fell within the election pending period. Mr Major replied later the same day saying that the decision to ban $\mathrm{Mr}$ Smith was "based on an overscrupulous reading of the guidance." $\mathrm{He}$ went on to say that "In these circumstances, I would be content for your visit to be covered by the media." A few minutes after this letter was received the hospital agreed to the visit.

(5) A senior manager in a purchasing organisation, who asked not to be named, said that the chief executive tried to dissuade him from submitting articles about the realities of commissioning that were critical of the NHS reforms. He was led to believe that publication of the articles would be detrimental to his career. He has submitted them anyway.

(6) John Wyn-Owen, director of the NHS in Wales, was replaced earlier this year by a civil servant. Civil servants must sign the Official Secrets Act and have very limited rights of free speech.

(7) The government proposes to make all regional directors of public health and directors of research and development into civil servants. In the past, regional directors of public health have been NHS employees who have a right to speak freely in public on behalf of their populations (see $\mathrm{p} \mathrm{0000)^{3 }}$ These directors will also not be able to run for office in professional organisations like the Faculty of Public Health Medicine or the BMA.

(8) Dr Sam Everington reported to a meeting of BMA Council that he had been unable to find a doctor willing to appear in a Labour party broadcast before the last general election. Doctors were too scared of reprisals. In the end the broadcast featured him, his wife, who is also a doctor, and the practice nurse from his surgery.

\section{Running of the NHS}

(9) Commissioning organisations are finding it increasingly difficult to get information from providers about fundholding general practices because it is considered to be commercially sensitive. One manager said, "For example, if we wanted to know how many hysterectomies were performed in our area last year, we know how many are performed on patients from non-fundholding general practices but not from fundholders. This is undermining the NHS's ability to look at the whole picture and plan accordingly. This is leading to a fragmentation of service planning and provision. And it's crazy because it's all taxpayers' money."

(10) Dr Sandy Macara said, "I am getting a steady flow of correspondence and personal communications 
from doctors who are scared stiff to be identified. They are unhappy about being instructed to give clinical priority to minor cases over more serious ones to make statistics look good, keep waiting lists down, and give priority to fundholding patients."

(11) In a survey published in April 1992 the Campaign for Freedom of Information said that the Department of Health refused to make public responses to its consultation document on the patient's charter, quoting the Official Secrets Act. The Official Secrets Act 1989 applies to defence, security, law enforcement, and international relations. Responses to a similar consultation by the Welsh office on the patient's charter are publicly available.

(12) The Sunday Times reported in April 1994 that Bridget O'Connell, a consultant paediatrician at King George's Hospital in Ilford, Essex, had been suspended on full pay for more than a decade. She was told her suspension was due to her "inability to relate effectively to her clinical colleagues." The suspension followed her repeated complaints about staffing levels in paediatric units under her control. The Department of Health does not keep national figures on the number of suspended doctors.

(13) Full labelling of a cosmetic product's ingredients has been compulsory in the United States since 1977. Manufacturers in Europe are not legally obliged to label ingredients and most do not.

(14) A BMA industrial relations officer has been denied access to an internal auditor's report which investigated the allegations made by a member of the BMA that $£ 250000$ from one department's budget is inappropriately accounted for. The member has alleged that his mail was redirected.

(15) Self governing trusts are obliged to hold one meeting a year in public. They must produce an annual report detailing their activities. Labour's research department found that many trusts charged up to $£ 17.50$ per report.

(16) Mr David Wrede, a member of the Junior Doctors' Committee, told me that it is increasingly difficult to find junior doctors who are willing to speak out. The new deal on junior doctors' hours is being reviewed later this month, and the committee is concerned that only senior members are willing to stand up and be counted.
(17) Dr John Spencer, consultant radiologist at Luton and Dunstable Hospital NHS Trust, took early retirement in April 1994 after discovering that the trust's chief executive had tapped his telephone. He signed an agreement not to speak publicly about the circumstance surrounding his retirement.

(18) Waiting time bulletins published biannually show only percentage changes. Information is no longer given about patients who have died or removed themselves from the list.

(19) The quarterly monitoring returns, which provide information about "finished consultant episodes," are still not published. This prevents people outside government from looking at trends.

(20) The white paper Open Government, published last year, contained a commitment to develop a code of practice on openness in the NHS by the end of 1994 . The aim is to encourage the NHS to make it easier for people to access information. The draft NHS Executive guidance on openness includes a section on information the NHS may refuse to release. This section includes information "which would take too much time to collect." It also includes "information about analysis, research, or statistics which is incomplete or has not yet been published."

(21) The Annual Report of the NHS, published a few weeks ago, is unreferenced. The report said: "Provisional figures suggest the target 'efficiency' of 2 per cent was comfortably exceeded-that is patient activity increased by over 2 per cent more than the increased amount spent on services." No details are given about how patient activity or the increase in spending was measured so it is impossible to know whether this claim of increased efficiency is justified.

(22) In March 1994 John Major announced a new system of categorising state secrets to reduce the number of classified documents. In November 1994 Labour MP Stephen Byers asked individual government departments for information on the numbers of "top secret" and "secret" files they hold. The Department of Health replied that they hold 413 secret files but would not give any indication of the category of secrecy.

(23) During the public consultation process before trust status was granted to a hospital in Scotland, some consultants from the hospital formed a group to oppose the application. One consultant was interviewed by a local television station and said that the trust had problems but also stated that it was too early to say whether the reforms were a success. After the programme was televised the consultant was told by the trust's medical director that the chief executive was angry about the comments.

(24) In November 1993 Dr Anila Reddy, a senior registrar at Raigmore Hospital NHS Trust in Inverness, went to the press about shortages of staff and low morale at the hospital. Trust managers contemplated disciplinary proceedings. Senior consultants at the hospital attempted to persuade the managers not to follow through this threat. Eventually the matter was dropped.

(25) In April 1994 a letter to the Raigmore trust's board chairman, Dr James Kyle, was leaked to the press. The letter criticised the "callousness" of managers and was signed by five senior consultants on behalf of all consultants. The leak caused another uproar, but Dr Kyle (a former consultant and BMA activist) dismissed the allegations as "virtually meaningless." Behind the scenes, the five consultant signatories to the letter were called to a meeting with the medical director. Strenuous attempts were made to find who had leaked the letter to the press, without success.

(26) A BMA industrial relations officer has told me that "we are aware that certain consultants are being 


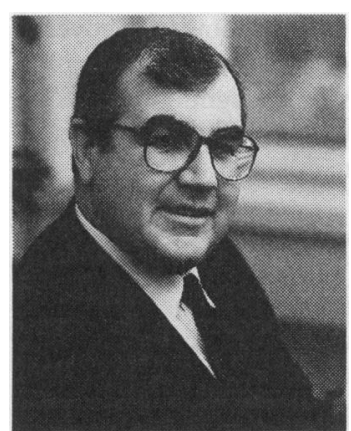

Alan Langlands, chief executive of the NHS offered inducements such as enhancements to salary and particularly generous removal expenses to take a post with a trust." Managers are allegedly offering such inducements subject to confidentiality being maintained.

\section{Parliamentary questions}

(27) The parliamentary unit at the BMA commented on the striking number of parliamentary questions that receive the answer "The information requested is not held centrally."

(28) In February 1993 Hansard reported that Ian McCartney, then opposition spokesman for health, asked the secretary of state for health what advice she had received from the independent assessors nominated by the Royal College of Pathologists on awarding the private contract for pathology services for the North Hertfordshire trust and what action was taken as a result of that advice. Tom Sackville, the under secretary of state for health, replied that "the advice of the assessors nominated by the Royal College of Pathologists was given in confidence to the North Hertfordshire trust. We understand that the trust has found the advice valuable in its discussions on the detail of the service to be provided under contract."

(29) In November 1994 Hansard reported that Jim Cousins, Labour spokesman on foreign affairs, asked the secretary of state for health "if she will place the Touche Ross report on the Prescription Pricing Authority in the Library." Gerry Malone replied "No. As part of the market testing process, a number of reports have been prepared for the Prescription Pricing Authority by Touche Ross and others. Those reports contain information which is commercially sensitive."

(30) In February 1994 Hansard reported that Gerry Steinberg (Labour, City of Durham) asked the secretary of state for health "if she will list by region the hospitals that have closed since 1990 and also those that have opened in the same time period." Tom Sackville replied that "Decisions on opening or closing facilities are for local management. The Department requires formal notification only where proposed closures are contested by the community health councils."

\section{Smith R. Twenty steps towards a "closed society" on health. BMf 1987;295: 1633-4. \\ Frankel M. Medical secrets. New Scientist 1994;Dec 3.51.}

3 Sheard S. Gagging public health doctors. BMF 1994;309:1643-4.

\section{Gagging public health doctors}

\author{
Sally Sheard
}

On 1 April 1996 the last vestiges of public health advocacy in Britain will be abolished when the eight regional health authorities are replaced by eight analogous NHS Executive regional offices.' The regional directors of public health and their staff will become civil servants and hence constrained in speaking out on matters of public health. One consequence will be that the directors, the leaders of public health medicine, will not be allowed to become office holders in the Faculty of Public Health Medicine.

From its inception, public health has held a unique place in the British medical establishment. Public health doctors must often speak out against governmental and public opinion in the interest of the public health. As our expectations for quality of life and health care have increased, so has the scope for intervention in all aspects of public and private life. Thus advocacy and the right of free speech have long been intrinsic components of the public health movement, and they have been regularly attacked.

\section{Conflicts of the first medical officer of health}

In 1847, after the appointment of William Henry Duncan in Liverpool as the country's first medical officer of health, Punch satirised the part time position which left Duncan at the mercy of his private patients. If the Officer of Health recommended by $\mathrm{Mr}$ Punch shall have for a patient a rich butcher, with a slaughter house in a populous neighbourhood, an opulent fellmonger or tallow chandler, with a yard or manufactory in heart of town, he shal not hesitate from motives of interest to denounce their respective establishments as nuisances, he shall not fail to point out the insalubrity of any gas-works, similarly situated, the family of whose proprietor he may attend; and if any old lady who may be in the habit of consulting him shall infringe the Drainage Act, he shall not fail to declare the circumstances to the authorities. ${ }^{2}$

Punch provided an amusing if crude description of the relationships which Duncan was forced to endure through his contract with Liverpool Town Council.
Thankfully, the council recognised the importance of the independent status for the officers of health, and Duncan was given a full time position later that year.

More recently, the royal colleges and the public health profession supported Keith Barron's Private Member's Bill for the Abolition of Tobacco Advertising. In response the Department of Health said that government policy superseded the established public health doctrine that smoking is harmful to health and that public health practitioners were in no position to advise members of parliament to support the bill. If this is the response of the Department of Health to public health practitioners who are still functionally independent from central government, what will happen in 1996?

\section{Closing the door on free speech}

Sadly, much of the freedom of public health professionals has already been surrendered. In 1988 the report of the Committee of Inquiry into the Future Development of the Public Health Function, which was chaired by the then chief medical officer, Sir Donald Acheson, concluded: "We therefore reject the view expressed in some of the evidence submitted to us that public health doctors, employed in the public sector, have a duty or a right to advocate or pursue policies which they judge to be in the public interest independently of any line of accountability. In the extreme this would place them in a position above Parliament."3

The Acheson report suggested that the advisory function would be most effectively carried out through representation to the local health authority, and in the same year the response from the president of the Faculty of Community Medicine concurred with this. ${ }^{4}$ Even by this date, however, the local health authorities had lost much of their independent status. The battle had effectively been lost in 1974, when centrally appointed health authorities inherited the responsi- 